\title{
Black Tea Flavonoids: A Focus on Thearubigins and their Potential Roles in Diet \& Health
}

\author{
Timothy Bond $\mathrm{J}^{1}$, and Emma Derbyshire $\mathrm{J}^{2 *}$ \\ ${ }^{1}$ Tea Advisory Panel; Tea and Herbal Solutions, Bedford, United Kingdom \\ ${ }^{2}$ Nutritional Insight, Epsom, Surrey, United Kingdom
}

*Corresponding author: Emma Derbyshire J, Nutritional Insight, Epsom, Surrey, United Kingdom, E-mail: emma@nutritional-insight.co.uk

Received: 15 Sep, 2020 | Accepted: 27 Oct, 2020 | Published: 02 Nov, 2020

Citation: Bond JT, Derbyshire JE (2020) Black Tea Flavonoids: A Focus on Thearubigins and their Potential Roles in Diet \& Health. Nutr Food Technol Open Access 6(2): dx.doi.org/10.16966/2470-6086.168

Copyright: (c) 2020 Bond JT, et al. This is an open-access article distributed under the terms of the Creative Commons Attribution License, which permits unrestricted use, distribution, and reproduction in any medium, provided the original author and source are credited.

\begin{abstract}
The potential health benefits of black tea are well documented but the specific roles of thearubigins are less widely published. We undertook a review to identify human observational studies and laboratory studies investigating inter-relationships between thearubigin intakes and health. Twenty-two publications were identified-five observational studies and 17 laboratory/mechanistic studies. Evidence from observational studies demonstrates that black tea is a major dietary provider of thearubigins, with reported intakes of $327 \mathrm{mg} / \mathrm{d}$ in the UK, a nation of tea drinkers but lower in Europe (156 $\mathrm{mg} / \mathrm{d}$ ). A growing body of evidence (from laboratory/cell studies) signifies that thearubigins could have potential health roles, including antioxidant, antimutagenic and anticancer properties, along with the ability to reduce inflammation and improve gastrointestinal motility. Well-designed human trials are now needed to further investigate thearubigin intakes from dietary sources in relation to specific health outcomes.
\end{abstract}

Keywords: Thearubigins, Black tea, Flavonoids, Health

\section{Introduction}

Black tea contains thousands of biological compounds which includes the flavonoid family (thearubigins, theaflavins and catechins) alongside many others such asproteins, amino acids (including L.theanine), phenolic acids (caffeic acid, gallic acid, chlorogenic acids and cauramic acid) vitamins (A, C and K),lipids and fluoride [1]. Thearubigins (TRs) are major components of black tea that provide its distinctive dark, brown colour [2,3]. It has been estimated that black tea TRs are the most abundant group of phenolic pigments accounting for an estimated $60 \%-82 \%$ of the solids in a typical infusion [4-6]. It is the TRs present in black tea, first identified in the 1960s that are attributed to its distinctive colour, mouth-feel and health properties $[2,7,8]$. From a dietary stance it has been shown that black tea is a predominant provider of phenolics with, on average, a cup of black tea providing polyphenols at the level of $262 \mathrm{mg}$ Gallic Acid Equivalents (GAE)/serving and TRs representing around 75$82 \%$ total phenolics [9]. In terms of desirability it has been reported that an optimum ratio of TF and TR (1:10 estimated by computational approach) is required to ensure a quality cup of tea and control the environment for oxidation [10].

TRs are produced during the aeration (previously but inaccurately called 'fermentation') of tea leaves [2,11]. Aeration, one of the main process stages of black tea production transforms over $75 \%$ catechins into polymers which include TRs, theaflavins (TFs) and theasinensins (TSs). Structurally flavonoids have a 'flavan skeleton' comprised of two aromatic rings linked by a three-carbon atom heterocyclic ring. In the ring all flavonoids have $\mathrm{OH}$ groups in the 5- and 7-position and on the $\mathrm{B}$ ring in the 3-position. They are formed when the enzyme polyphenoloxidase converts -epigallocatechins and -epigallocatechin3-O-gallate into TF's and TRs (Figure 1) [11].

Investigations into TR chemistry and isolation/fractionation have been undertaken since the 1960's but a great deal about their specific structure is unknown. It is agreed though that the flavonoid structure remains a key structural moiety in the TR structure (Figure 2). An analysis of TR fractions from 15 teas showed that their structures were no more than 2000Da whilst more than 5000 individual chemical entities were identified [4]. Other work studying the formation of TRs and their chemical structure found that condensation reactions between the A-ring and B-ring were particularly important for TR formation [12]

The potential health properties of black tea are well established $[13,14]$. A meta-analysis of 10 studies found black tea consumption can be associated with significant reductions in serum low-density lipoprotein cholesterol levels, particularly amongst those with higher cardiovascular risk [15]. A prior review of 19 meta-analysis and 23 randomised controlled trials ( $n=1,422$ participants) linked tea drinking to improved blood pressure regulation (particularly those 


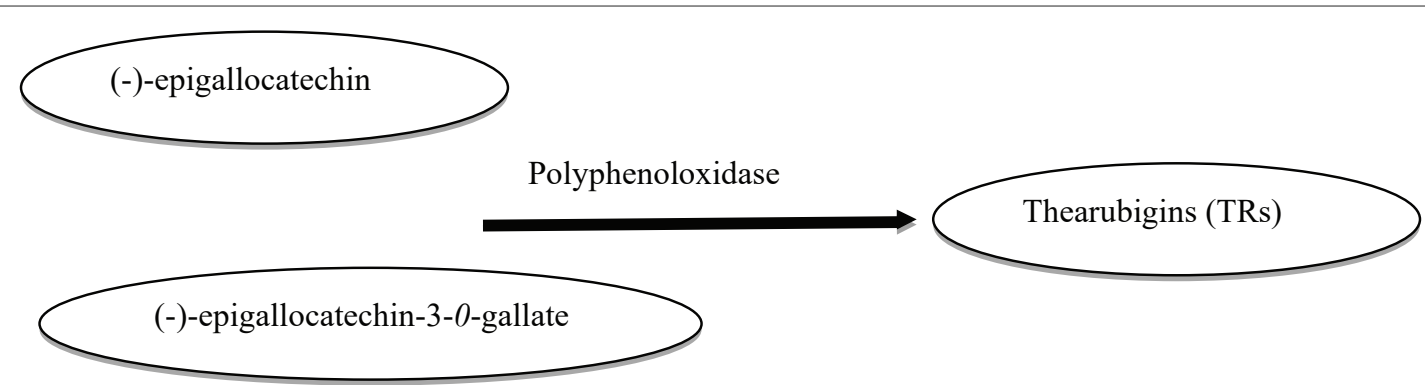

Figure 1: Black tea leaf chemistry.

Source: Adapted from Haslam E (2003) [11].

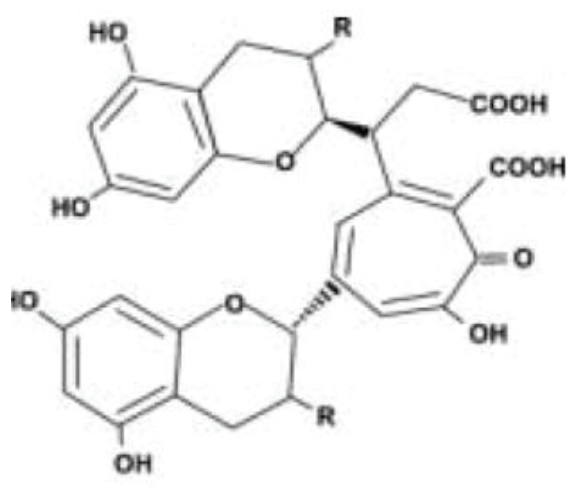

Figure 2: Thearubigin Proposed Structure.

Source: Khan N, et al. (2007) [47] and Koch W (2020) [54].

with pre/hypertension), vascular function and inflammation [16]. Black tea polyphenols also appear to attenuate obesity and associated comorbidities by: 1) inhibiting saccharide and lipid absorption, digestion and intake, 2) stimulating lipid metabolism and 3) reducing oxidative stress [17]. Black tea phytochemicals have further been linked to the regulation of molecular targets including COX-2, 5-LOX, AP-1, JNK, STAT, EGFR, AKT, Bcl, NF- $\kappa B$, Bcl-xL, caspases, p53, FOXO1, TNFa, PARP, and MAPK, possibly exerting anticarcinogenic properties [18].

Now, TRs are being identified as one of the main bioactive components present in black tea that could be attributed to some of these health effects $[7,15]$. In particular, TRs can protect against oxidative stress by a variety of means, including the inhibition of: 1) redox-sensitive transcription factors, 2) pro-oxidant enzymes and 3) redox-sensitive transcription factors [19]. Some other proposed biofunctions of TRs include their potential antioxidant, antimutagenic, anticancer effects and ability to modulate gastrointestinal motility and skeletal health $[7,20]$.

Given growing evidence on the TR component of black tea, the aim of the present review was to collate evidence on TRs in relation to dietary intakes and implications for health, using data from observational studies and animal/cell models. Such a review does not appear to have been undertaken previously.

\section{Materials and Methods}

\section{Search strategy}

A generic search for "Thearubigin*" was undertaken using the National Institutes of Health's National Library of Medicine PubMed database. This was used to identify relevant human and laboratory studies. Studies focusing on green, herbal or other teas were not included. Publications that focused on flavonoids but did not collect or report data on TRs were also excluded. Reference lists were also searched for further relevant publications. The algorithm used to identify and select studies is shown in Figure 2.

Filters were applied and the inclusion criterion was defined as: (1) English-language publications, (2) papers published in the last 20 years, (3) human studies-only those investigating TR intakes and any associations with health were included and (4) animal/mechanistic studies investigating inter-relationships between TRs and markers of health.

\section{Study quality}

The STROBE (Strengthening the reporting of observational studies in epidemiology) checklist was used to identify the quality of human observational studies [21]. A maximum score of 22 could be achieved with this meaning that all the STROBE reporting recommendations had been achieved. Publications were regarded as being methodologically excellent if they received a STROBE score over 20 and methodologically strong if they received a STROBE score between 15 and 20 .

For laboratory/mechanistic studies the Systematic Review Center for Laboratory animal Experimentation (SYRCLE) approach was used [22]. This was comprised of six stages: 1) developing the research question "do TRs influence markers of health?", 2) searching for evidence, 3) selecting studies, 4) extracting study characteristics (Table $1), 5)$ assessing quality bias tool was applied [23] and 6) providing an overview of findings [22].

\section{Results}

\section{Habitual intakes}

Of the 41 human studies identified, 36 were excluded due to them being review papers $(n=13)$, irrelevant $(n=13)$, laboratory studies $(n=6)$ or a quantitative analysis of TR profiles $(n=4)$ (Figure 3$)$. This 
Table 1: Habitual Intakes of TRs and reported associations with health.

\begin{tabular}{|c|c|c|c|c|c|c|}
\hline $\begin{array}{l}\text { Author (Year), } \\
\text { Country }\end{array}$ & $\begin{array}{c}\text { Study } \\
\text { Population }\end{array}$ & Study Type & $\begin{array}{l}\text { Estimation of daily } \\
\text { intake based on. }\end{array}$ & $\begin{array}{l}\text { Habitual intakes } \\
(\mathrm{mg} / \mathrm{d})\end{array}$ & Other findings. & $\begin{array}{l}\text { STROBE } \\
\text { Score. }\end{array}$ \\
\hline $\begin{array}{l}\text { Murphy KJ, et al. } \\
\text { (2019) [26] Australia }\end{array}$ & 39 to 65 years & Cross-sectional & $\begin{array}{l}\text { Total Flavonoids } \\
\text { TRs }(58 \%)\end{array}$ & $\begin{array}{l}\text { Total } 626 \\
\text { M } 566 \\
\text { F } 660 \\
\text { Total } 363 \\
\text { M } 328 \\
\text { F } 383\end{array}$ & $\begin{array}{l}\text { TR accounted for } 58 \% \text { of the } \\
\text { flavonoid intake. }\end{array}$ & Strong \\
\hline $\begin{array}{l}\text { Kim YJ, et al. (2015) } \\
\text { [27] Korea }\end{array}$ & 1 year+ & Cross-sectional & TR & $\begin{array}{l}2.3 \mathrm{mg} / \mathrm{d} \text { per unit } \\
\text { capita }\end{array}$ & $\begin{array}{l}\text { Single food items accounting } \\
\text { for more than } 50 \% \text { of the } \\
\text { intake of a specific flavonoid } \\
\text { included black tea (TR) }\end{array}$ & Strong \\
\hline $\begin{array}{l}\text { Vogiatzoglouet A, } \\
\text { al. (2015) [24] UK } \\
\text { (European Data) }\end{array}$ & $18-64$ years & $\begin{array}{l}\text { Observational-Used } \\
\text { data from the EFSA } \\
\text { and FLAVIOLA } \\
\text { Food Composition } \\
\text { Database }\end{array}$ & TRs & $\begin{array}{c}\text { UK } 327 \\
\text { Europe } 156\end{array}$ & $\begin{array}{l}\text { Non-alcoholic beverages, } \\
\text { particularly tea was the } \\
\text { main source of total and } \\
\text { monomeric flavonoids in the } \\
\text { European Union. }\end{array}$ & Strong \\
\hline $\begin{array}{l}\text { Zamora-Ros R, et al. } \\
\text { (2013) [25] Europe/ } \\
\text { UK }\end{array}$ & $\begin{array}{c}<35 \text { or }>74 \\
\text { years }\end{array}$ & Cohort & TRs & $\begin{array}{c}\text { M } 403 \\
\text { F } 571 \\
M \text { (health conscious) } \\
113 \\
F \text { (health conscious) } \\
196\end{array}$ & $\begin{array}{c}\text { TR could account } \\
\text { approximately for half of the } \\
\text { total flavonoids in countries } \\
\text { where tea is highly consumed, } \\
\text { particularly black tea. }\end{array}$ & Strong \\
\hline $\begin{array}{l}\text { Cui Y, et al. (2008) } \\
\text { [28] US }\end{array}$ & 18 to 65 years & $\begin{array}{l}\text { Population-based } \\
\text { case-control }\end{array}$ & TR & $\begin{array}{c}\text { Median, } 4 \\
\text { Interquartile range, } 24\end{array}$ & $\begin{array}{c}\text { Regardless of smoking status, } \\
\text { there was little association } \\
\text { with between total TRs and } \\
\text { lung cancer risk. }\end{array}$ & Excellent \\
\hline
\end{tabular}

left five observational studies that investigated TR intakes from dietary sources thus were included in the review (Table 1). Of these studies, two used European data [24,25], one was conducted in Australia [26], one in Korea [27] and one in the US [28].

The European Prospective Investigation into Cancer and Nutrition (EPIC) collated data from 36,037 adults (35-74 years) finding that TR intakes ranged from $0.9 \mathrm{mg} /$ day in men from Navarra and San Sebastian in Spain to $532.5 \mathrm{mg} /$ day amongst UK males [25]. TR intakes averaged out across Europe were $156 \mathrm{mg} / \mathrm{d}$ and much higher in the UK at $327 \mathrm{mg} / \mathrm{d}$ [25]. Other data from the European Food Safety Authority (EFSA) and the FLAVIOLA Food Composition Database showed that mean total flavonoid intake was $428 \pm 49 \mathrm{mg} / \mathrm{d}$ [24]. Again, TRs and theaflavins $(\approx 168 \mathrm{mg} / \mathrm{d})$ were the main types of flavonoids consumed (TR's contributing $156 \mathrm{mg}$ /day), predominantly from tea [24].

In Australia, a cross-sectional study ( $\mathrm{n}=1183$ adults) reported total daily flavonoid intakes to be $626 \pm 579 \mathrm{mg} / \mathrm{d}$ with TRs accounting for 58 per cent of the total flavonoids $(\approx 363 \mathrm{mg} / \mathrm{d})$ [26]. The flavonoids and TRs consumption of women were found to be higher compared to men, and tea was found to be the main provider of these [26]. In Korea the mean energy-adjusted total flavonoid intake was $107 \mathrm{mg} / \mathrm{d}$ and black tea accounted for more than $>50 \%$ of the TR intake [27]. Similarly, lower intakes have been reported in the US-median TR intakes of $4 \mathrm{mg} / \mathrm{d}$ which were not inversely associated with lung cancer amongst tobacco smokers [28].

Of the observational studies undertaken, after applying STROBE scores these tended to be methodologically excellent or strong. Failure to describe efforts to address potential sources of bias, fully report statistical methods, including justification of sample size and reasons for non-participation at each study stage were some of the main limitations and not always consistently reported in the identified observational studies.

\section{Laboratory/Mechanistic Studies}

Of the 45 studies initially identified 28 were excluded- 15 were not related to TRs, seven were outside of the scope of the review, and six were review papers (Figure 3). Subsequently seventeen laboratory studies investigated TRs in relation to markers of health and were included in the present review. Of these twelve were animal studies and five were studies using cell models (Table 2).

Regarding health outcomes these varied widely between studies. Three laboratory studies indicated that there could be potential benefits to gastrointestinal function [29-31]. Early work by Chauduri L, et al. [29] using a murine model showed that the TR fraction of black tea significantly increased gastrointestinal transit, implying that TRs are involved with the prokinetic effects of black tea. A similar model by Murad HAS, et al. (2014) [30] found that black tea extract providing TRs reversed the motility-delaying effects of sildenafil which relaxes muscles of blood vessels. Other work using a mouse model of inflammatory bowel disease showed that TRs significantly attenuated diarrhoea and the disruption of colonic architecture [31]. Levels of neutrophil inflammation and lipid peroxidation were also significantly reduced in the inflamed colon in this study [31].

Five cell studies focused on cancer cell growth [32-36]. Early work by Sakamoto K (2000) discovered that TRs, when administered alone, did not alter cell growth. However, when combined with genistein cell growth was significantly reduced and a G2/M phase cell cycle arrest induced in a dose-dependent manner [36]. Other work using Ames Salmonella assays has shown that black tea and its associated TR polyphenols exhibit antimutagenic effects [35]. The same team found 
Table 2: Laboratory /Mechanistic Studies.

\begin{tabular}{|c|c|c|c|}
\hline Author (year) Country & Laboratory model & Intervention & Findings \\
\hline \multicolumn{4}{|c|}{ Studies on Animals. } \\
\hline $\begin{array}{l}\text { Wang X, et al. (2019) [38] } \\
\text { China }\end{array}$ & Neonatal rats & Natural bioactive compound TR. & $\begin{array}{l}\text { TR caused a significant reduction in lung } \\
\text { inflammation. }\end{array}$ \\
\hline $\begin{array}{l}\text { Imran A, et al. (2018) [14] } \\
\text { Pakistan }\end{array}$ & $\begin{array}{l}\text { Model feeding trial } \\
\text { using Wistar rats }\end{array}$ & $\begin{array}{l}\text { TF \&TRs isolated from black tea and utilize to } \\
\text { form three types of nutraceutical drinks. }\end{array}$ & $\begin{array}{c}\text { The TF+ TRs based drink caused highest glucose } \\
\text { decline and maximum insulin increase. }\end{array}$ \\
\hline $\begin{array}{l}\text { Liang Q, et al. (2018) [55] } \\
\text { China }\end{array}$ & In Vitro Rat Model & Low-dose TRs, and high-dose TRs group. & $\begin{array}{l}\text { TRs inhibited osteoclastogenesis } \& \text { diminished } \\
\text { expression levels of related genes \& proteins. }\end{array}$ \\
\hline $\begin{array}{l}\text { Murad HA, et al. (2016) [40] } \\
\text { Egypt }\end{array}$ & Mouse model & $\begin{array}{c}\text { Treated intraperitoneally as follows: NAC (318 } \\
\mathrm{mg} / \mathrm{kg}), \mathrm{BTE}(3 \%, 4.5 \%) \text {, and TRs }(50,60 \text {, and } \\
70 \mathrm{mg} / \mathrm{kg})\end{array}$ & $\begin{array}{l}\text { The APAP-accumulated apoptotic cells in } \\
\text { sub-G1 phase were significantly decreased by } \\
\text { treatments, mostly by NAC and TRs70 in the } \\
\text { liver and TRs }(60,70) \text { in kidneys. }\end{array}$ \\
\hline $\begin{array}{l}\text { Murad HAS, et al. (2014) } \\
\text { [30] Egypt }\end{array}$ & Mouse model & $\begin{array}{l}\text { Different concentrations of BTE, TRs, and } \\
\text { sildenafil. }\end{array}$ & $\begin{array}{c}\text { BTE } 4.5 \% \text { or TRs } 60 \mathrm{mg} / \mathrm{kg} \text { could be considered } \\
\text { as a reliever therapy for the sildenafil-induced } \\
\text { dyspepsia. }\end{array}$ \\
\hline $\begin{array}{l}\text { Negishiet H, et al. (2004) } \\
\text { [39] Japan }\end{array}$ & Rat model & $\begin{array}{l}\text { Control group; the black tea polyphenol group } \\
\text { (3.5 g/L thearubigins, } 0.6 \mathrm{~g} / \mathrm{L} \text { theaflavins, } 0.5 \\
\mathrm{~g} / \mathrm{L} \text { flavonols and } 0.4 \mathrm{~g} / \mathrm{L} \text { catechins) and the } \\
\text { green tea polyphenol group. }\end{array}$ & $\begin{array}{l}\text { Systolic and diastolic BP were significantly lower } \\
\text { in the BTP and GTP groups than in the controls. }\end{array}$ \\
\hline $\begin{array}{l}\text { Maityet S, et al. (2003) [31] } \\
\text { India }\end{array}$ & Mouse model & TR (40 or $100 \mathrm{mg}$ kg(-1) day(-1) for 10 days) & TR had beneficial effects in experimental colitis. \\
\hline $\begin{array}{l}\text { Gupta S, et al. (2001) [37] } \\
\text { India }\end{array}$ & Albino mice study & $\begin{array}{c}\text { Three different concentrations }(5,10 \text { and } 20 \%) \\
\text { of tea and a single dose of TF and TR tested }\end{array}$ & $\begin{array}{l}\text { Black tea and its active polyphenols TR and TF } \\
\text { had significant anticlastogenic effects in bone } \\
\text { marrow cells of mice. }\end{array}$ \\
\hline $\begin{array}{l}\text { Satoh E, et al. (2002) [43] } \\
\text { Japan }\end{array}$ & Mouse study & TR fraction extracted from a black tea infusion & $\begin{array}{l}\text { The TR fraction protects against the action of } \\
\text { tetanus toxin by binding with the toxin. }\end{array}$ \\
\hline $\begin{array}{l}\text { Satoh E, et al. (2001) [41] } \\
\text { Japan }\end{array}$ & Mouse study & BTE or TR fraction & $\begin{array}{c}\text { Black tea TR may help protect against the } \\
\text { paralytic actions of BoNTs, }\end{array}$ \\
\hline $\begin{array}{l}\text { Satoh E, et al. (2001) [42] } \\
\text { Japan }\end{array}$ & Mouse study & $\begin{array}{l}\text { Hot water infusion of black tea mixed with } \\
\text { tetanus toxin }\end{array}$ & $\begin{array}{l}\text { TR fraction counteracts the effect of tetanus } \\
\text { toxin by binding with toxin, and also suggest } \\
\text { that this fraction may be able to apply for } \\
\text { prophylaxis of tetanus. }\end{array}$ \\
\hline $\begin{array}{l}\text { Chaudari, et al. (2000) [29] } \\
\text { India }\end{array}$ & Mouse study & Hot water and black tea interventions & $\begin{array}{l}\text { The TR fraction (but not TF) accelerated GIT } \\
\text { significantly which suggests a prokinetic effect. }\end{array}$ \\
\hline \multicolumn{4}{|l|}{ Studies on Cells. } \\
\hline $\begin{array}{l}\text { Imran A, et al. (2019) [32] } \\
\text { Pakistan }\end{array}$ & $\begin{array}{l}\text { Colon and Lung } \\
\text { cancer cells }\end{array}$ & $\mathrm{TF}, \mathrm{TR}$, and their combinations & $\begin{array}{c}\text { Black tea polyphenols (Inc. TR) exhibited a } \\
\text { significant inhibition of lung and colon cancer } \\
\text { cell growth. }\end{array}$ \\
\hline $\begin{array}{l}\text { Bhattacharya U, et al. (2011) } \\
\text { [33] India }\end{array}$ & $\begin{array}{l}\text { Salmonella strains } \\
\text { used. }\end{array}$ & $\begin{array}{l}\text { Three fractions of TR were isolated by } \\
\text { chromatographic processes. }\end{array}$ & $\begin{array}{l}\text { Antimutagenic and anticancer activities of the } \\
\text { TR-1, TR-2, and TR-3 fractions on Salmonella } \\
\text { strains and on U937 cells were found, } \\
\text { respectively esp TR-2. }\end{array}$ \\
\hline $\begin{array}{l}\text { Halder B, et al. (2006) [34] } \\
\text { India }\end{array}$ & $\begin{array}{l}\text { In vitro in bacterial } \\
\text { system and In vivo in } \\
\text { mouse bone marrow } \\
\text { cells }\end{array}$ & Black tea polyphenols TF and TR & $\begin{array}{c}\text { TF and TR had significant anticlastogenic effects } \\
\text { in vitro in human lymphocytes. }\end{array}$ \\
\hline $\begin{array}{l}\text { Gupta S, et al (2002) [35] } \\
\text { India }\end{array}$ & Salmonella strains & Black tea & $\begin{array}{l}\text { TR and TF showed significant antimutagenic } \\
\text { effects against known positive compounds in } \\
\text { these strains. }\end{array}$ \\
\hline $\begin{array}{l}\text { Sakamoto K, et al. (2000) } \\
\text { [36] USA }\end{array}$ & $\begin{array}{l}\text { Human prostate } \\
\text { carcinoma cells }\end{array}$ & $\begin{array}{l}\text { Black tea polyphenol, TR, alone or combined } \\
\text { with the isoflavone }\end{array}$ & $\begin{array}{l}\text { TR significantly inhibited cell growth and } \\
\text { induced a G2/M phase cell cycle arrest in a } \\
\text { dose dependent manner. }\end{array}$ \\
\hline
\end{tabular}


that black tea and its active polyphenols, including TR had significant anticlastogenic effects (inhibiting damage to chromosomes) in murine bone marrow cells [37]. Similarly, Halder et al. [34] observed that TR and TF had anticlastogenic effects in human lymphocytes. More recently, Imran et al. [32] studied colon and lung cancer cell lines concluding that TR and TF had promising synergistic effects as inhibitors of cancer cells. Other work by Bhattacharya et al. [33] found that particular TR fractions had antimutagenic and anticancer activity, with TR-2 appearing to be a particularly active component of TR.

Three laboratory studies investigated markers of metabolic control or inflammation [14,38,39]. One study [14] using a nutraceutical beverage providing TRs and TFs found that this induced the largest glucose decline and maximum insulin release, suggesting a potential to attenuate hypercholesterolemia and hyperglycaemia disorders as a parallel therapy. Negishi H, et al. [39] using a stroke-prone hypertensive laboratory model showed that black polyphenols attenuated blood pressure increases potentially via their antioxidant properties. Wang $\mathrm{X}$, et al. [38] found that TR has strong antioxidant properties that appear to reduced neonatal acute lung injury, possibly by reducing oxygen species levels.

Murine models have also shown that TRs protect against acetaminophen-induced hepatotoxicity and nephrotoxicity, again potentially via their antioxidant activity [40]. Other research suggests that TR fractions could protect against tetanus and botulinum neurotoxins [41-43].

Regarding quality, when applying the SYRCLE approach most laboratory/mechanistic studies were well designed, reporting their methodologies in detail. When considering forms of bias, performance bias was most frequent amongst laboratory studies. For example, not all studies documented or clearly reported how animals were randomly allocated to groups, blinded or housed [23]. Future studies also need to report more consistently whether study subjects were selected at random to prevent detection bias as this was not always evident.

\section{Discussion}

For green tea, the health roles of catechins are well documented, particularly in the case of epigallocatechin gallate [44-46]. There is an established body of evidence linking black tea consumption and its associated polyphenols to pharmacological effects including antioxidant, antimicrobial, cholesterol-lowering and cardioprotective properties $[1,15,47,48]$. Now, it is becoming increasingly evident that black tea and its associated TR profile could possess a range of important biofunctions [7].

Tea polyphenols, including TR appear to have a place in the diet and potential to influence the pathogenesis of certain chronic diseases through the bioactivities that they possess $[47,48]$. The present review collated evidence from 5 human observational studies and 17 laboratory and cell studies. Observational research determining habitual TR intakes showed that these vary widely. For example, European data reported TR intakes of $6 \mathrm{mg} / \mathrm{d}$ in Spain and $327 \mathrm{mg} / \mathrm{d}$ in the United Kingdom [24]. Bearing this in mind effects on health outcomes would not be expected in regions with such low habitual intakes. Subsequently, further epidemiological studies are needed to study inter-relationships between TR intakes and health outcomes with focus on countries with higher habitual intakes.

Diet diaries are known to be fallible when self-reporting food intakes. Another area that might cause some inconsistencies is the method of calculation and inclusion of 'thearubigins' in flavonoid/ nutrient databases. The USDA database includes TRs under green tea and in some instances theaflavins are included. The latter is not found in well-made green tea so could be artifacts [49]. Additionally

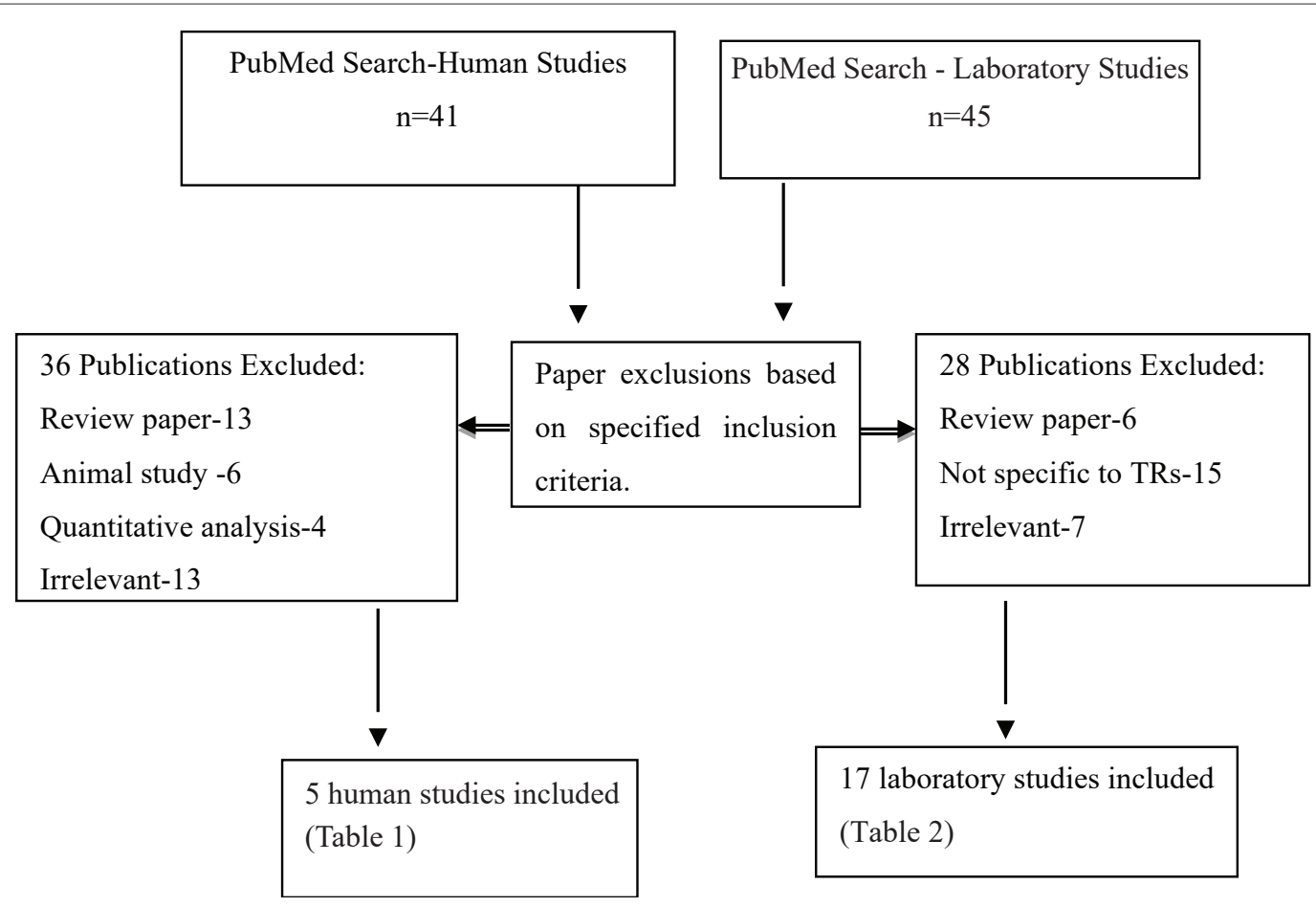

Figure 3: Algorithm for database search results. 
although Stewart et al reported that as $30 \%$ of green tea antioxidants are not HPLC resolvable these species are more likely to be higher molecular weight species such as proanthocyanidin oligomers and polymers, rather than true TR's [6].

Laboratory/mechanistic studies investigated inter-relationships between TRs and a range of health outcomes. In particular, TRs ability to exhibit anticancer effects, by inhibiting cell growth and having antimutagenic effectslook particularly interesting [32,35,36]. TRs also appear to lower blood pressure and improve glucose, insulin and inflammatory profiles $[14,38,39]$. Some studies imply benefits for gastrointestinal motility $[29,30]$. Similar conclusions have been drawn elsewhere, with the main biofunctions of TRs reported to include anticancer and antimutagenic effects, antioxidation and improved gastrointestinal motility [7]. A growing body of evidence is also beginning to study the role of Mitochondrial Activation Factor (MAF), a black tea polyphenol that appears to promote glycolysis and lipolysis in liver cells and improve fatty liver [50]. Clearly, human studies in the form of randomised controlled trials are now needed to build on these findings.

With regard to future work steps are needed to develop databases of bioactive compounds and improve the accuracy and precision of these [51]. Large-scale human trials usingstandardised TR fractions, rigorous blinding methods and controls are also warranted to study the effects of TRs in relation to specific health outcomes. Further epidemiological studies would be useful to better understand how higher TR intakes could impact on health when compared to other regions. Further research on the absorption and metabolism of TRs after ingestion is also needed as this appears to be highly variable [52]. TR's are formed during the aeration stage of black tea manufacture thus the amount of TR formed overall will be a factor of the original catechin content (which can vary between varieties) and the time/ conditions of aeration. Studies often use commercially available blended tea or do not state the source of the tea. The method of isolation of the TR fraction can also vary giving further complications in comparing studies.

From a public health stance, consumers can be guided about the general health benefits of polyphenols and flavonoids, including TRs and the main dietary sources of these. Even though polyphenols are regarded as 'non-nutrients' are they increasingly being found to have a protective effects against certain noncommunicable diseases and metaflammation (a subclinical, permanent inflammation) [5355]. Whilst health professionals may be aware of the generic health properties of black tea, greater awareness about the aetiology and potential physiological roles of TR is likely needed.

\section{Conclusions}

In summary, the health benefits for certain tea components including green tea catechins is well established whilst the role of TRs has tended to be overlooked. TRs are one of the most abundant phenolic components present in black tea and evidence studying the underpinning health mechanisms of these has been accruing. Laboratory study evidence implies that TRs are important antioxidants and appear to possess anticancer, antimutagenic, anti-inflammatory and gastrointestinal motility regulatory effects. Well-designed human trials are now needed to build on these emerging findings.

\section{Acknowledgments}

Conflicts of Interest: The authors received funding provided by the Tea Advisory Panel (www.teaadvisorypanel.com), which is supported by an unrestricted educational grant from the UK TEA \&
INFUSIONS ASSOCIATION (UKTIA), the trade association for the UK tea industry. UKTIA plays no role in producing the outputs of the panel. Independent panel members include nutritionists, biochemists, dieticians, dentist and doctors.

\section{References}

1. Naveed M, BiBi J, Kamboh AA, Suheryani I, Kakar I, et al. (2018) Pharmacological values and therapeutic properties of black tea (Camellia sinensis): A comprehensive overview. Biomed Pharmacother 100: 521-531.

2. Wang W, Zhang S, Lv L, Sang S (2018) A new method to prepare and redefine black tea thearubigins. J Chromatogr A 1563: 82-88.

3. Sang S (2016) Tea: Chemistry and ProcessingEncyclopedia of Food and Health.

4. Kuhnert N (2010) Unraveling the structure of the black tea thearubigins. Arch Biochem Biophys 501: 37-51.

5. Kuhnert N, Drynan JW, Obuchowicz J, Clifford MN, Witt M (2010) Mass spectrometric characterization of black tea thearubigins leading to an oxidative cascade hypothesis for thearubigin formation. Rapid Commun Mass Spectrom 24: 3387-3404.

6. Stewart AJ, Mullen W, Crozier A (2005) On-line high-performance liquid chromatography analysis of the antioxidant activity of phenolic compounds in green and black tea. Mol Nutr Food Res 49: 52-60.

7. Zhu K, Ouyang J, Huang J, Liu Z (2020) Research progress of black tea thearubigins: a review. Crit Rev Food Sci Nutr 29: 1-11.

8. Roberts EAH, Smith RF (1963) The phenolic substances of manufactured tea. IX.†-the spectrophotometric evaluation of tea liquors. J Sci Food Agri 14: 158.

9. Rechner AR, Wagner E, Van Buren L, Van De Put F, Wiseman S, et al. (2002) Black tea represents a major source of dietary phenolics among regular tea drinkers. Free Radic Res 36: 1127-1135.

10. Pou JKR (2016) Fermentation: The Key Step in the Processing of Black Tea. J Biosys Engineering 41: 85-92.

11. Haslam E (2003) Thoughts on thearubigins. Phytochemistry 64: 61-73.

12. Uchida K, Ogawa K, Yanase E (2016) Structure Determination of Novel Oxidation Products from Epicatechin: Thearubigin-Like Molecules. Molecules 21: 273.

13. Chen ZM, Lin $Z$ (2015) Tea and human health: biomedical functions of tea active components and current issues. J Zhejiang Univ Sci B 16: 87-102.

14. Imran A, Butt MS, Arshad MS, Arshad MU, Saeed F, et al. (2018) Exploring the potential of black tea based flavonoids against hyperlipidemia related disorders. Lipids Health Dis 17: 57.

15. Zhao Y, Asimi S, Wu K, Zheng J, Li D (2015) Black tea consumption and serum cholesterol concentration: Systematic review and metaanalysis of randomized controlled trials. Clin Nutr 34: 612-619.

16. Etheridge $\mathrm{C}$, Bond $\mathrm{T}$, Derbyshire $\mathrm{E}$ (2018) Effects of Tea Consumption on Measures of Cardiovascular Disease: A Systematic Review of Meta-Analysis Studies and Randomised Controlled Trials. J NutriFood Sci 8: 4.

17. Pan H, Gao Y, Tu Y (2016) Mechanisms of Body Weight Reduction by Black Tea Polyphenols. Molecules 21: 1659.

18. Singh BN, Rawat AK, Bhagat RM, Singh BR (2017) Black tea: Phytochemicals, cancer chemoprevention, and clinical studies. Crit Rev Food Sci Nutr 57: 1394-1410. 
19. Butt MS, Imran A, Sharif MK, Ahmad RS, Xiao H, et al. (2014) Black tea polyphenols: a mechanistic treatise. Crit Rev Food Sci Nutr54: 1002-1111.

20. Krishnan R, Maru GB (2004) Inhibitory effect(s) of polymeric black tea polyphenol fractions on the formation of $[(3) \mathrm{H}]-\mathrm{B}(\mathrm{a}) \mathrm{P}$-derived DNA adducts. J Agric Food Chem 52: 4261-4269.

21. STROBE (2009) STROBE Statement.

22. SYRCLE (2019) SYstematic Review Center for Laboratory animal Experimentation.

23. Hooijmans $C R$, Rovers $M M$, de Vries RB, Leenaars $M$, RitskesHoitinga M, et al. (2014) SYRCLE"s risk of bias tool for animal studies. BMC Med Res Methodol 14: 43.

24. Vogiatzoglou A, Mulligan AA, Lentjes MA, Luben RN, Spencer JP, et al. (2015) Flavonoid intake in European adults (18 to 64 years). PLoS One 10: e0128132.

25. Zamora-Ros R, Knaze V, Romieu I, Scalbert A, Slimani N, et al. (2013) Impact of thearubigins on the estimation of total dietary flavonoids in the European Prospective Investigation into Cancer and Nutrition (EPIC) study. Eur J Clin Nutr 67: 779-782.

26. Murphy KJ, Walker KM, Dyer KA, Bryan J (2019) Estimation of daily intake of flavonoids and major food sources in middle-aged Australian men and women. Nutr Res 61: 64-81.

27. Kim YJ, Park MY, Chang N, Kwon O (2015) Intake and major sources of dietary flavonoid in Korean adults: Korean National Health and Nutrition Examination Survey 2010-2012. Asia Pac J Clin Nutr 24: 456-463.

28. Cui Y, Morgenstern H, Greenland S, Tashkin DP, Mao JT, et al. (2008) Dietary flavonoid intake and lung cancer--a population-based casecontrol study. Cancer 112: 2241-2248.

29. Chaudhuri L, Basu S, Seth P, Chaudhuri T, Besra SE, et al. (2000) Prokinetic effect of black tea on gastrointestinal motility. Life Sci 66: 847-854.

30. Murad HAS, Abdallah HM (2014) Black tea extract and its thearubigins relieve the sildenafil-induced delayed gut motility in mice: a possible role of nitric oxide. Phytother Res 28: 1687-1691.

31. Maity S, Ukil A, Karmakar S, Datta N, Chaudhuri T, et al. (2003) Thearubigin, the major polyphenol of black tea, ameliorates mucosal injury in trinitrobenzene sulfonic acid-induced colitis. Eur J Pharmacol 470: 103-112.

32. Imran A, Butt MS, Xiao H, Imran M, Rauf A, et al. (2019) Inhibitory effect of black tea (Camellia sinensis) theaflavins and thearubigins against HCT 116 colon cancer cells and HT 460 lung cancer cells. J Food Biochem 43: e12822.

33. Bhattacharya U, Mukhopadhyay S, Giri AK (2011) Comparative antimutagenic and anticancer activity of three fractions of black tea polyphenols thearubigins. Nutr Cancer 63: 1122-1132.

34. Halder B, Pramanick S, Mukhopadhyay S, Giri AK (2006.) Anticlastogenic effects of black tea polyphenols theaflavins and thearubigins in human lymphocytes in vitro. Toxicol In Vitro 20: 608613.

35. Gupta S, Chaudhuri T, Seth P, Ganguly DK, Giri AK (2002) Antimutagenic effects of black tea (World Blend) and its two active polyphenols theaflavins and thearubigins in Salmonella assays. Phytother Res 16: 655-661.

36. Sakamoto K (2000) Synergistic effects of thearubigin and genistein on human prostate tumor cell (PC-3) growth via cell cycle arrest. Cancer Lett 151: 103-109.
37. Gupta S, Chaudhuri T, Ganguly DK, Giri AK. (2001) Anticlastogenic effects of black tea (World blend) and its two active polyphenols theaflavins and thearubigins in vivo in Swiss albino mice. Life Sci 69: 2735-2744.

38. Wang $X$, He $P$, Yi S, Wang $C$ (2019) Thearubigin regulates the production of Nrf2 and alleviates LPS-induced acute lung injury in neonatal rats. 3 Biotech 9: 451.

39. Negishi H, Xu JW, Ikeda K, Njelekela M, Nara Y, et al. (2004) Black and green tea polyphenols attenuate blood pressure increases in strokeprone spontaneously hypertensive rats. J Nutr 134: 38-42.

40. Murad HA, Habib H, Kamel Y, Alsayed S, Shakweer M, et al. (2016) Thearubigins protect against acetaminophen-induced hepatic and renal injury in mice: biochemical, histopathological, immunohistochemical, and flow cytometry study. Drug Chem Toxicol 39: 190-198.

41. Satoh E, Ishii T, Shimizu Y, Sawamura S, Nishimura M (2001) Black tea extract, thearubigin fraction, counteract the effects of botulinum neurotoxins in mice. Br J Pharmacol 132: 797-798.

42. Satoh E, Ishii T, Shimizu Y, Sawamura S, Nishimura M (2001) Black tea extract, thearubigin fraction, counteracts the effect of tetanus toxin in mice. Exp Biol Med (Maywood) 226: 577-580.

43. Satoh E, Ishii T, Shimizu Y, Sawamura S, Nishimura M (2002) A mechanism of the thearubigin fraction of black tea (Camellia sinensis) extract protecting against the effect of tetanus toxin. J Toxicol Sci 27: 441-447.

44. Pervin M, Unno K, Takagaki A, Isemura M, Nakamura Y (2019) Function of Green Tea Catechins in the Brain: Epigallocatechin Gallate and its Metabolites. Int J Mol Sci 20: 3630.

45. Higdon JV, Frei B (2003) Tea catechins and polyphenols: health effects, metabolism, and antioxidant functions. Crit Rev Food Sci Nutr 43: 89-143.

46. Farzaei MH, Bahramsoltani R, Abbasabadi Z, Braidy N, Nabavi SM (2019) Role of green tea catechins in prevention of age-related cognitive decline: Pharmacological targets and clinical perspective. J Cell Physiol 234: 2447-2459.

47. Khan N, Mukhtar H (2007) Tea polyphenols for health promotion Life Sci 81: 519-533.

48. Khan N, Mukhtar H (2018) Tea Polyphenols in Promotion of Human Health. Nutrients 11: 39

49. Bhagwat S, Haytowitz DB, Nutrient Data Laboratory, Beltsville Human Nutrition Research Center, Agricultural Research Service, et al. (2015) USDA, USDA Database for the Flavonoid Content of Selected Foods. Release 3.2.

50. Numata O (2017) Effects of High Molecular-Weight Polyphenol (Mitochondria Activation Factor) Derived from Black Tea and Oolong Tea on Mitochondria Function. In: Health Benefits of Green Tea: An Evidence-Based Approach, Hara Y, et al. CABI: 191.

51. Peterson JJ, Dwyer JT, Jacques PF, McCullough ML (2015) Improving the estimation of flavonoid intake for study of health outcomes. Nutr Rev73: 553-576.

52. Clifford MN, van der Hooft JJ, Crozier A (2013) Human studies on the absorption, distribution, metabolism, and excretion of tea polyphenols. Am J Clin Nutr 98: 1619S-1630S.

53. Koch W (2019) Dietary Polyphenols-Important Non-Nutrients in the Prevention of Chronic Noncommunicable Diseases. A Systematic Review. Nutrients 11: 1039. 
54. Koch W (2020) Theaflavins, Thearubigins, and Theasinensins. Xiao J, et al. Handbook of Dietary Phytochem Free Radic Res, Singapore Springer Nature Singapore Pte Ltd.

55. Liang Q, Lv M, Zhang X, Hu J, Wu Y, et al. (2018) Effect of Black Tea Extract and Thearubigins on Osteoporosis in Rats and Osteoclast Formation in vitro. Front Physiol 9: 1225. 